\title{
Molecular detection of the Hepatitis C virus genotypes circulating among both sexes of Khyber Pakhtunkhwa, Pakistan
}

\author{
Habib Ur Rehman', Muhammad Waqar,,4, Muhammad Wasim³ ${ }^{3}$ Asad Ullah Khan ${ }^{5}$, Agha Asad Noor \\ Tauseef Ahmad ${ }^{5}$, Niyaz Ali ${ }^{5}$, Tariq Shah ${ }^{5}$, Faisal ${ }^{5}$, Zeeshan $\mathrm{Niaz}^{5}$, Shaista Bano Memon ${ }^{4}$, Noor ul Akbar ${ }^{6}$, \\ Mubarak Zeb ${ }^{4,7}$, Effa Khan ${ }^{7}$, Aisha Sheikh ${ }^{4}$ \\ ${ }^{1}$ Department of Medicine, Mardan Complex Hospital, Mardan, ${ }^{2}$ Genome Center for Molecular Diagnostics \& Research Lahore, Pakistan, \\ ${ }^{3}$ Khyber Medical Collage, Peshawar Khyber Pakhtunkhwa, Pakistan, ${ }^{4}$ Institute of Microbiology University of Sindh Jamshoro, Pakistan, \\ ${ }^{5}$ Department of Microbiology, Hazara University Mansehra, Khyber Pakhtunkhwa, Pakistan, ${ }^{6}$ Department of Zoology Kohat University Khyber \\ Pakhtunkhwa, Pakistan, ${ }^{7}$ Department of Microbiology Zia Uddin Hospital Karachi, Pakistan
}

\section{A B S TR A C T}

Background: Hepatitis C Virus (HCV) is the major cause of viral hepatitis. A few studies revealed that HCV genotypes; $3 a, 3 b, 1 a$ and $1 \mathrm{~b}$ are the most common genotypes found in the general population of Khyber Pakhtunkhwa. Aims and Objective: The current is designed to find out the prevalence of HCV genotypes among both sexes of Khyber Pakhtunkhwa. Study Methods: The present study was carried out in various area of Khyber Pakhtunkhwa during the period of July, 2012 to July, 2013. All the HCV positive samples were genotyped. The statistical analysis of the data was done by using Statistix 9.0 software. Result: The results showed that the male, $53.1 \%(n=340)$ were more infected as to female, $46.8 \%$ $(n=300)$. The overall result shows that in male patients; the high number of cases (216) was reported of $3 \mathrm{a}$ whereas the lowest cases (8) were reported of $1 \mathrm{~b}$. The mixed genotype is recorded in 8 patients. In female patients; the $3 a$ is detected in 170 patients whereas the lowest cases of genotype (3b) are reported in 5 patients. In female patients; the mixed genotype is reported in 11 patients. Conclusion: From the present study, it was concluded that the male were more infected as compare to female and the genotype $3 a$ was the most common genotype in both sexes.

Key words: Hepatitis C Virus, Genotypes, Chi-square test, GCMD

\section{INTRODUCTION}

Hepatitis C Virus is an envelope, single stranded RNA virus with a genome size of $9.6 \mathrm{~kb}$. HCV was first time discovered by Choo in 1989 and was placed in family Flaviviridae and genus Hepacivirus. ${ }^{1,2}$ Hepatitis C Virus is similar to dengue, Yellow fever and Hepatitis G viruses. ${ }^{3}$ In human HCV can lead to chronic and acute hepatic inflammation. ${ }^{4} \mathrm{HCV}$ is mostly responsible for chronic hepatitis, Hepatocellular carcinoma and liver cirrhosis. ${ }^{5}$ Globally, HCV infects about 170 million of the world population. Hepatitis C Virus infection is distributed globally but its prevalence varies from area to area. ${ }^{6}$ Because of the limited resources and low facilities, HCV infection rate is high when compare with developed countries. ${ }^{7}$ From different regions of Pakistan, many uncontrolled outbreaks of HCV infection have been reported. ${ }^{8}$ Hepatocytes and B lymphocytes are targeted by Hepatitis C Virus and about 10 trillion new viral particles are produced per day. ${ }^{9}$

HCV can transmit through many sources, i.e., re-use of syringes, improper blood screening before transfusion, sharing of razors, unsafe sex, etc. In Pakistan, key factors that are responsible for Hepatitis $\mathrm{C}$ Virus infection are blood transfusion, re-use of syringes and needles used for nose and ear piercing, re-use of blades in the barber shop and contaminated surgical instrument. ${ }^{10,11}$ Due to genetic variation in nucleotide sequences, $\mathrm{HCV}$ is further classified 
into various genotypes. ${ }^{12} \mathrm{Up}$ to date six principal genotypes and almost 80 subtypes of Hepatitis $C$ Virus are identified around the world. ${ }^{13} \mathrm{HCV}$ genotype 1,2 and 3 are circulating worldwide while the remaining genotypes vary from region to region. $\mathrm{HCV}$ subtypes $1 \mathrm{a}$ and $1 \mathrm{~b}$ are most commonly distributed throughout the world especially in Europe and USA. ${ }^{14,15}$ Subtype $1 \mathrm{~b}$ is responsible for $73 \%$ of $\mathrm{HCV}$ infection in Japan. Subtype $2 \mathrm{a}$ and $2 \mathrm{~b}$ are most common in Europe and North America while 2c are mostly found in Northern Italy. ${ }^{10} \mathrm{HCV}$ genotype 3 is most dominant genotype in South-East Asia while in Egypt, Central Africa and Middle East; genotype 4 is mostly distributed. Genotype 5 infects most of the population of South Africa ${ }^{16}$ while genotype 6 is most common in Hong Kong. ${ }^{17}$

A few numbers of studies on HCV genotype distribution are available from Khyber Pakhtunkhwa that based on small samples sizes. ${ }^{18}$ Recently, a less number of studies on the distribution of $\mathrm{HCV}$ genotypes is reported from Khyber Pakhtunkhwa which shows that 3a, 3b, 1a and $1 \mathrm{~b}$ are the most common genotypes found in the general population in Khyber Pakhtunkhwa. ${ }^{19}$ The present research study was conducted to analyze the prevalence of $\mathrm{HCV}$ genotypes between both sexes of various areas of Khyber Pakhtunkhwa.

\section{MATERIALS AND METHODS}

\section{Study area}

This study was conducted at the Mardan medical complex from July, 2012 to July, 2013. Khyber Pakhtunkhwa is the beautiful place on the earth that consists of 24 districts with an area of $74521 \mathrm{sq} \mathrm{km}$, and a population of 0.22 billion. $\mathrm{HCV}$ positive males and females patients from 10 to 75 years of various districts of Khyber Pakhtunkhwa were selected in our study. Out of the total 640 patients, 267(41.7\%) belong to district Peshawar, 219(34.2\%) to district Mardan, 96(15\%) to district Swat, 20(3.1\%) to district Malakand, 15(2.3\%) to district Dir lower, $12(1.8 \%)$ to district Abottabad and $11(1.7 \%)$ to district D. I. Khan. Blood samples were collected from all the patients and serum were separated from it and send to Genome Center for Molecular Based Diagnostics $\&$ Research for screening of HCV infection.

\section{Viral RNA isolation}

Viral RNA was isolated from $150 \mu$ l of patient's samples by using Nucleo Spin DNA Virus/Virus F kits by Machery and Nagel, isolation kit according to instruction provided by manufacture.

\section{HCV genotyping}

For genotyping of HCV Ana Gen (USA) Kit was used. First of all complementary DNA was synthesized from
$10 \mu \mathrm{l}$ of extracted RNA at $37^{\circ} \mathrm{C}$ in 50 min with the help of MMLV(Molony-murine leukemia virus) enzymes. Complementary DNA was further subjected into two round of PCR amplification. About $2 \mu \mathrm{l}$ of $\mathrm{cDNA}$ was used to amplify 470-bp region from HCV 5’NCR+Core region in $1^{\text {st }}$ round PCR. After that, $1^{\text {st }}$ round PCR product were subjected into two round of nested PCR. First with mixed-A primers and $2^{\text {nd }}$ with mixed-B primers. Mixed A primers consist of $1 \mathrm{a}, 1 \mathrm{~b}, 1 \mathrm{c}, 3 \mathrm{a}, 3 \mathrm{c}$ and 4 and mixed-B primers consist of $2 \mathrm{a}, 2 \mathrm{c}, 3 \mathrm{~b}, 5 \mathrm{a}$ and $6 \mathrm{a}$. Finally the amplify PCR product were run on $2 \%$ agarose gel, stained with ethidium bromide and visualized under UV transilluminator. The genotype-specific cDNA bands identified the HCV genotype in each sample.

\section{Statistical analysis}

Statistical analysis was done by using Statistic 9.0 software. Chi-square test was used for variable categorization. P-value less than 0.05 were considered as significant.

\section{RESULTS}

\section{A. Prevalence of HCV genotype circulating in different area of Khyber Pakhtunkhwa}

In the present study, only those patients were included that were found positive for HCV RNA through PCR. Out of $640 \mathrm{HCV}$ positive patients, $46.8 \%(\mathrm{n}=300)$ were females and male $53.1 \%(n=340)$. All the patients belong to different regions of Khyber Pakhtunkhwa. Ages of these patients are from 10 years to 80 years. Table 1 analyzed distribution of HCV genotypes in various regions of Khyber Pakhtunkhwa. In total of these $640 \mathrm{HCV}$ positive patients, 267 patients belong to District Peshawar in which 136 patients were found with genotype 3a, 40 patients with genotype 1a, 9 patients with $1 \mathrm{~b}, 2$ patients with $3 \mathrm{~b}, 3$ patients with mixed genotypes and 77 patients were found untypable. From District Mardan 219 patients were selected where 149 patients were found with 3 a genotype, 25 with 1 b, 10 with $1 \mathrm{~b}, 6$ with $3 \mathrm{~b}, 8$ with mixed genotype and 21 were untypable. From District Swat, $96 \mathrm{HCV}$ positive patients were analyzed where genotype distribution were 3a; (68), 1a; (13), 1b; (3), 3b; (2), mixed genotype; (1), while 9 patients were found untypable. Sum of 20 patients from district Malakand were screened for HCV genotypes in which genotype $3 a$ is most common that is found in 7 patients, 1a was found in 2 patients, $3 \mathrm{~b}$ in 3 patients, 3 patients found with mixed genotype and 2 patients were found untypable. Fifteen patients from District Dir lower were screened for HCV genotyping in which distribution pattern of HCV genotypes was 3a; (7), 1b; (1), mixed genotype; (3) and untypable; (4). In district Abottabad, 12 patients were checked for $\mathrm{HCV}$ genotyping in which genotype $3 \mathrm{a}$ is mostly distributed, $3 \mathrm{~b}$ was detected in 2 patients, 1 patient with mixed genotypes 
and 2 patients was found untypable. In district D. I. Khan 3a genotype was found in 9 patients, $1 \mathrm{a}$ in 1 patient and 1 patient was untypable.

\section{B. Presence of HCV genotypes in both sexes of Khyber Pakhtunkhwa}

Presence of different HCV genotypes in both sexes (males; $\mathrm{n}=340$ and females; $\mathrm{n}=300$ ) were analyzed in Table 2. Results show that $3 \mathrm{a}$ is the most common genotype among both sexes. In male patient, genotype 3 a was found in 216 patients, $1 \mathrm{a}$ in 39 patients, $1 \mathrm{~b}$ in 8 patients, $3 \mathrm{~b}$ in 10 patients and 8 patients were found infected by two genotype (mixed genotype) while in the remaining 59 patients, none of the genotype were observed. It was considered untypable genotype according to Ohno et al [20]. Our results show that the total 300 females patient, HCV genotype 3 a was detected in 170 patients, $1 \mathrm{a}$ in 43 patients, $1 \mathrm{~b}$ in 14 patients, $3 \mathrm{~b}$ in 5 patients while 11 patients was found with mixed genotype and 57 patients were found untypable.

\section{Distribution of HCV mixed genotypes in both sexes of various area of Khyber Pakhtunkhwa}

In our study, it is observed that 19 of the patients were found infected by combination of two genotypes. Table 3 indicated that 11 patients were infected by combination of two genotype $3 a+1 a, 5$ were infected by $3 a+1 b$ and 3 were infected by $3 \mathrm{a}+3 \mathrm{~b}$. In total of 19 patients, 3 patients belong to district Peshawar, 8 to district Mardan, 1 to district Swat, 3 to district Malakand, 3 to district Dir lower and 1 to district Abottabad.

\section{DISCUSSIONS}

Khyber Pakhtunkhwa is one of the four Provinces of Pakistan that is located in the north-west of the country.
It has the second poorest economy after Balochistan. ${ }^{21}$ So it is comprehensible that health facilities like screening and sterilization are not up to par, leading to spread of blood-borne infections like HCV. HCV has been divided into six major types and several minor subtypes. ${ }^{22}$ Knowledge of its subtypes is crucial for clinical management, ie., for estimation of prognosis and duration of treatment and vaccine development. According to the WHO estimates, $3 \%$ of the worldwide population is infected with the Hepatitis C Virus. ${ }^{23} \mathrm{HCV}$ genotypes have heterogeneous geographical distribution. Genotypes 1, 2 and 3 have a global distribution while 4, 5 and 6 are restricted to more precise geographic regions, i.e., South Africa and Southeast Asia, Egypt and Africa respectively. ${ }^{22}$ Pakistan has a high prevalence rate of Hepatitis $C$ ranging from $4.5 \%$ to $8 \% .{ }^{24}$ A detailed study from Pakistan showed the prevalence of genotype $3 \mathrm{a}$ $(62 \%), 3 \mathrm{~b}(9 \%), 1 \mathrm{a}(3 \%), 2 \mathrm{a}(2.144 \%)$, mixed $(4.718 \%)$ and untypable $(17.16 \%) .{ }^{25} \mathrm{~A}$ study from KPK done on IDUs in 2011 showed that genotype 2a was the most prevalent followed by $3 \mathrm{a}$, and that a considerable number of the IDUs were infected with genotype 4 also. ${ }^{26} \mathrm{~A}$ study from Swat also showed similar results. ${ }^{27}$ Similar pattern was observed in Sindh and Punjab provinces with Baluchistan showing disparity in that genotype 1a was found to be most predominant. ${ }^{28}$

Our study is pertinent because all areas of KPK have been covered, including Swat, Mardan, Peshawar, Malakand, Dir (Lower), Abbotabad and D. I. Khan. This is in contrast to most other KPK studies which were limited to just one region. Such kind of extensive study was therefore needed and would give a far better picture of the over-all prevalence of genotypes in KPK, and differences in its region-wise, so that a more advanced study can be

\begin{tabular}{|c|c|c|c|c|c|c|c|c|}
\hline $\begin{array}{l}\text { Genotype/ } \\
\text { Sub-types }\end{array}$ & $\begin{array}{l}\text { District } \\
\text { Peshawer }\end{array}$ & $\begin{array}{l}\text { District } \\
\text { Mardan }\end{array}$ & $\begin{array}{c}\text { District } \\
\text { Swat }\end{array}$ & $\begin{array}{c}\text { District } \\
\text { Bathkhela }\end{array}$ & $\begin{array}{l}\text { District } \\
\text { Dir lower }\end{array}$ & $\begin{array}{c}\text { District } \\
\text { Abottabad }\end{array}$ & $\begin{array}{l}\text { District } \\
\text { D.I. Khan }\end{array}$ & P-value \\
\hline $1 a$ & $40(14.9 \%)$ & $25(11.4 \%)$ & $13(13.5 \%)$ & $02(10 \%)$ & $01(6.6 \%)$ & 00 & $01(9 \%)$ & \multirow{7}{*}{$\begin{array}{c}0.0000 \\
\text { significant }\end{array}$} \\
\hline $1 \mathrm{~b}$ & $09(3.3 \%)$ & $10(4.5 \%)$ & $03(3.1 \%)$ & 00 & 00 & 00 & 00 & \\
\hline $3 a$ & $136(50.9 \%)$ & $149(68 \%)$ & $68(70.8 \%)$ & $10(50 \%)$ & $07(46.6 \%)$ & $07(58.3 \%)$ & $09(81.8 \%)$ & \\
\hline $3 b$ & $02(0.7 \%)$ & $06(2.7 \%)$ & $02(2.08 \%)$ & $03(15 \%)$ & 00 & $02(16.6 \%)$ & 00 & \\
\hline Mixed genotypes & $03(1.1 \%)$ & $08(3.6 \%)$ & 01 (1.04\%) & $03(15 \%)$ & $03(20 \%)$ & $01(8.3 \%)$ & 00 & \\
\hline Untypable & $77(28.8 \%)$ & $21(9.5 \%)$ & $09(9.3 \%)$ & $02(10 \%)$ & $04(26.6 \%)$ & $02(16.6 \%)$ & $01(9 \%)$ & \\
\hline Total & 267 & 219 & 96 & 20 & 15 & 12 & 11 & \\
\hline
\end{tabular}

\begin{tabular}{|c|c|c|c|c|c|}
\hline Genotypes & Subtypes & Male & Female & Total & P-value \\
\hline \multirow[t]{2}{*}{1} & $1 a$ & $39(11.4 \%)$ & $43(14.3 \%)$ & $82(12.8 \%)$ & \\
\hline & $1 b$ & $8(2.3 \%)$ & $14(4.6 \%)$ & $22(3.4 \%)$ & \\
\hline \multirow[t]{2}{*}{3} & 3a & $216(63.5 \%)$ & $170(56.6 \%)$ & $386(60.3 \%)$ & 0.9928 \\
\hline & $3 b$ & $10(2.9 \%)$ & $05(1.6 \%)$ & $15(2.3 \%)$ & Non-significant \\
\hline Mixed & & $08(2.3 \%)$ & $11(1.7 \%)$ & 19 (2.9\%) & \\
\hline Untypable & & $59(17.3 \%)$ & $57(19 \%)$ & $116(18.1 \%)$ & \\
\hline
\end{tabular}




\begin{tabular}{|c|c|c|c|c|c|c|c|}
\hline \multirow[t]{2}{*}{ District } & \multicolumn{2}{|c|}{$3 a+1 a$} & \multicolumn{2}{|c|}{$3 a+1 b$} & \multicolumn{2}{|c|}{$3 a+3 b$} & \multirow[t]{2}{*}{$\mathrm{P}$-value } \\
\hline & Male & Female & Male & Female & Male & Female & \\
\hline Peshawar & 0 & 01 & 01 & 0 & 0 & 01 & \multirow{7}{*}{$\begin{array}{c}0.6721 \\
\text { Non- } \\
\text { significant }\end{array}$} \\
\hline Mardan & 02 & 02 & 03 & 0 & 0 & 01 & \\
\hline Swat & 0 & 01 & 0 & 0 & 0 & 0 & \\
\hline Malakand & 0 & 02 & 01 & 0 & 0 & 0 & \\
\hline Dir lower & 01 & 01 & 0 & 0 & 01 & 0 & \\
\hline Abottabad & 01 & 0 & 0 & 0 & 0 & 0 & \\
\hline Total & 11 & & 5 & & 3 & & \\
\hline
\end{tabular}

undertaken in future to investigate the reasons behind the differences and similarities. This in turn can help in prevention and treatment. Also, in most of the earlier studies, women subjects were limitedly selected because of the social and religious taboos which prevent them from participation in such studies, and also because females are less likely to be exposed to risk factors like intravenous drug abuse and unsafe sexual activities. For instance, in study conducted in KPK in 2011 on prevalence of HCV genotypes, only two females were analyzed from the whole population for HCV infection. ${ }^{29}$ However, in our study, the proportions of male and female subjects are almost equal. This can help in ruling out gender bias. Moreover, special stress has been given on determining the distribution of patients with mixed genotypes, as this greatly affects the treatment modality and prediction of outcome.

The results of our study are in accordance with the earlier studies which show that genotype 3 a outnumbers all other genotypes irrespective of region or gender. Our study also showed an outstanding proportion of untypable genotype which is in conformity with the other studies conducted in Pakistan. This study suggests that our beautiful province of KPK has been engulfed by the rising flood of HCV infection, specifically the genotype 3 a. Phenomenal steps need to be taken to combat this avalanche of spread especially of rare as well as untypable genotypes which are most probably mutants which can be resistant to conventional therapies. Sequencing of the untypable genotype is needed as this may open the door to the discovery of optimal therapy for such strains. Therefore, it is high time that updating of the current laboratory genotyping assays is done.

\section{CONCLUSIONS}

From the current study, it was concluded that the high prevalence rate of HCV is recorded in male population as compare to female population. It was observed that the HCV genotype $3 \mathrm{a}$ is the most common genotype in different areas of the Khyber Pakhtunkhwa, Pakistan.

\section{ACKNOWLEDGEMENT}

We are thankful to GCMD for supporting of this study. Also thanks to Mr. Murad Khan and Yahya Khan for his co-operation in this study.

\section{REFERENCES}

1. Choo QL, Kuo G, Weiner AJ, Overby LR, Bradley DW, Houghton, et al. Isolation of a cDNA clone derived from a bloodborne non-A, non-B viral hepatitis genome. Science 1989; 244(4902):359-362.

2. Kato, N. Molecular virology of hepatitis C virus. Acta. Med. Okayama. 2001;55:133-159.

3. Robertson B, Myers G, Howard C, Brettin T, Bukh J, Gaschen BT, et al. Classification, nomenclature and database development for Hepatitis C Virus (HCV) and related viruses: proposals for standardization. International Committee on Virus Taxonomy. Arch Virol 1998;143(12):2493-2503.

4. Sharma SD. Hepatitis C Virus: Molecular biology \& current therapeutic options. Indian J Med Res 2010;131:17-34.

5. Brass V, Moradpour D, and Blum HE. 2006. Molecular virology of Hepatitis C Virus (HCV). Int J Med Sci 2006; 3(2):29-34.

6. Frank C, Mohamed MK, Strickland GT, Lavanchy D, Aurthur RR, Magder LS, et al. The role of parenteral antischistosomal therapy in the spread of Hepatitis C Virus in Egypt. Lancet 2000; 355(9207):887-891.

7. Re VL and Kostman JR. Management of chronic Hepatitis C. Postgrad. Med J 2005;81:376-382.

8. Bari A, Akhtar S, Rahbar $\mathrm{MH}$ and Luby SP. Risk factors for Hepatitis C Virus infection in male adults in RawalpindiIslamabad, Pakistan. Trop Medic Int Health 2001; 6:732-738.

9. James MC. Liver and biliary tract. In: Kumar V, Abul KA, Nelson F, editors. Robins and Cotran Pathologic basis of Disease (7th ed.). Philadelphia: Elsevier; 2004. 935.

10. Ali S, Ali I, Azam S and Ahmad B. Frequency distribution of HCV genotypes among chronic Hepatitis C patients of Khyber Pakhtunkhwa. Virol J. 2011;8:193.

11. Lavanchy D. Evolving epidemiology of Hepatitis C Virus. Clin Microbiol Infect 2011;17:107-115.

12. Choo QL, Richman KH, Han JH, Berger K, Lee C, Dong C, et al. Genetic organization and diversity of the Hepatitis $C$ Virus. Proc Natl Acad Sci USA 1991; 88(6):2451-2455.

13. Simmonds P, Bukh J, Combet C, Deleage G, Enomoto N, Feinstone $\mathrm{S}$, et al. Consensus proposals for a unified system of nomenclature of Hepatitis C Virus genotypes. Hepatology 2005; 42(4):962-973.

14. Foote BC, Spooner LM and Belliveau PP. Boceprevir a protease inhibitor for the treatment of chronic Hepatitis C. Ann Pharmacother 2011;45(9):1085-1093.

15. Ashfaq UA, Khan SN, Nawaz Z and Riazuddin S. In-vitro model systems to study Hepatitis $C$ Virus. Genet Vaccines Ther 2011;9:7.

16. Kamal SM and Nasse Al. Hepatitis C genotype 4: What we know and what we don't yet know. Hepatology 2008;47:1371-1383.

17. Chao DT, Abe $\mathrm{K}$ and Nguyen MH. Systematic review: Epidemiology of Hepatitis $\mathrm{C}$ genotype 6 and its management. Aliment Pharmacol Ther 2011;34:286-296.

18. Abdulkarim AS, Zein NN, Germer JJ, Kolbert CP, Kabbani L, Krajnik KL, et al. Hepatitis C virus genotypes and Hepatitis $G$ Virus in hemodialysis patients from Syria: identification 
of two novel Hepatitis C Virus subtypes. Am J Trop Med Hyg 1998;59:571-576.

19. Ali A, Ahmed $\mathrm{H}$ and Idrees M. Molecular epidemiology of Hepatitis $\mathrm{C}$ virus genotypes in Khyber Pakhtoonkhaw of Pakistan. Virol J 2010;203:1-7.

20. Ohno O, Mezokami M, Wu R, Saleh MG, Ohba K, Orito E, et al. New Hepatitis C Virus (HCV) genotyping system that allows for identification of HCV genotypes $1 \mathrm{a}, 1 \mathrm{~b}, 2 \mathrm{a}, 2 \mathrm{~b}, 3 \mathrm{a}, 3 \mathrm{~b}, 4,5 \mathrm{a}$, and 6a. J Clin Microbiol 1997;35:201-202.

21. http://en.wikipedia.org/wiki/Khyber_Pakhtunkhwa

22. Afridi $S Q$, Zahid $M N$, Shabbir MZ, Hussain Z, Mukhtar N, Tipu MY, et al. Prevalence of HCV genotypes in district Mardan. Virol J 2013; 10:90.

23. WHO Hep C fact sheet No. 164, Geneva

24. Khattak MF, Salamat N, Bhatti FA and Qureshi TZ. Seroprevalence of Hepatitis B, C and HIV in blood donors in northern Pakistan. J Pak Med Assoc. 2002;52:398-402.
25. Butt S, Idrees M, Akbar H, Rehman I, Awan Z, Afzal S, et al The changing epidemiology pattern and frequency distribution of Hepatitis C Virus in Pakistan. Infection, Genetics and Evolution. 2010;10(5)595-600.

26. Rehman LU, Ullah I, Ali I, Khan IA, Iqbal A, Khan S, et al. Active Hepatitis $C$ infection and HCV genotypes prevalent among the IDUs of Khyber Pakhtunkhwa. Virol J 2011;8:327.

27. Ahmad A, Ahmad B, Ali A and Ahmad Y. Seroprevalence of $\mathrm{HBsAg}$ and anti-HCV in general healthy population of swat district with frequency of different HCV genotypes. Pak J Med Sci 2009;25(5):744-748.

28. Idrees $M$ and Riazuddin S. Frequency distribution of Hepatitis $C$ Virus genotypes in different geographical regions of Pakistan and their possible routes of transmission. BMC Infectious Diseases 2008; 8:69.

29. Rehman LU, Ullah I, Ali I, Khan I, Iqbal A, Khan S, et al. Active hepatitis $\mathrm{C}$ infection and HCV genotypes prevalent among the IDUs of Khyber Pakhtunkhwa. Virol J 2011; 8:327.

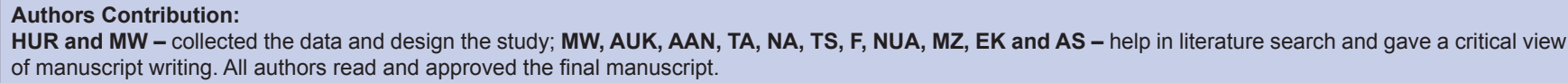

